\title{
Work Motivation of Satuan Intelkam Members of Polres Palopo in Terms of Surat Keterangan Catatan Kepolisian (SKCK) Management Services
}

\author{
Esti Retno Mustikorini' ${ }^{1}$, M. Risal ${ }^{2}$, and Muchtar Surullah ${ }^{3}$ \\ \{estirm@student.umpalopo.ac.id ${ }^{1}$, mrisal@umpalopo.ac.id ${ }^{2}$, muchtarsurullah@umpalopo.ac.id ${ }^{3}$ \} \\ Postgraduate of Management, Universitas Muhammadiyah Palopo \\ Jalan Jendral Sudirman Km. 3. Binturu Kota Palopo, 91922, Indonesia
}

\begin{abstract}
From the results of this study, it was found that there is enhancement in the issuance of SKCK (Surat Keterangan Catatan Kepolisian) at Polres Palopo. SKCK applicant data for the last 4 years from 2016 to 2019 continues to increase. The number of SKCK applicants was 5,271 in 2016, it was 5,685 in 2017, it was 6,567 in 2018 and it was 6,997 in 2019. Based on these data, it can be concluded that there are responsibility and work motivation of Satuan Intelkam members. The purpose of this study was to clearly identify and describe the extent of the work motivation of Satuan Intelkam Polres Palopo in terms of the quality of SKCK services. This research was a qualitative descriptive study. The data source was taken from the Internal Archives and structured interviews with three members of Satuan Intelkam with the sampling technique of the proposal.
\end{abstract}

Keywords: work motivation, service quality, SKCK

\section{Introduction}

The development of technology aims to make humans to work easier. This is found to make work faster. Individual work requires encouragement both internally and externally in order to be more active in completing the tasks. There are six cultural dimensions of police work including authoritarianism, alienation, social, cohesion and loyalty[1]

One of the national organization that has a strategic and important role in the administration of Republic of Indonesia is National Police of the Republic of Indonesia. In addition to Presidential Decree Number 89 of 2000, the legal basis for the main tasks and functions of the National Police is regulated in Law No. 2 of 2002 concerning the National Police of the Republic of Indonesia which states that the task of the national police is to provide basic services needed by the community. One of the forms of service provided is giving Surat Keterangan Catatan Kepolisian (SKCK). The function of SKCK is to explain the activities record of a person committing a crime to identify a valid identity of a person. SKCK can be used as one of the requirements for applying for a job, marrying a member of the TNI/Polri, applying for a scholarship and for other required requirements. SKCK has a validity period of up to 6 (six) months from the date of issuance of SKCK and if it has passed the validity period and is still needed, SKCK can be extended. The work activities discussed in this study were the work activities of members of Satuan Intelkam Polres Palopo. The purpose of this study was to determine and describe the extent of work motivation of Satuan Intelkam Polres Palopo in the SKCK management in the working area 
As a state instrument, the role and function of the National Police has not run maximally, as reported in KOMPAS.com online news on March 26, 2020, at 18:25 WIB Indonesian National Police temporarily closed SKCK and Crowd Permit Services. This was done to break the chain of Corona virus spread.

Satuan Intelkam Polres Palopo allegedly having a low level of motivation in serving SKCK management in the work area, which causes slow service and gives a bad impression to the community.

\section{Literature Review}

Humans move because there are goals to be achieved and expect that the work will bring to a condition to fulfill the needs of themselves from before[2]. Before describing work motivation specifically, it will be explained in advance about the definition of motivation, because these two words form one thing that is difficult to separate, motivation in the opinion of Vroom[3], is an act of directing in deciding how much effort to exert effort in a particular situation. While the definition of motivation according to Keitner \& Kinicki is a psychological process that causes inception of an action that has a direction to achieve certain goals[4],[5] and [6] motivation is defined as "to push and push strongly" which will be seen in persistent behavior in directing the achievement of certain goals.[7] defines Motivation as a willingness to express high ability to achieve organizational goals, which are based on the ability to meet some individual needs.

Based on the description above, it can be concluded that the definition of motivation is an encouragement that originates from a person / man himself to fulfill the needs in order to achieve the expected goals. Motivation is an important action because with the motivation it is expected that members will want to work according to the direction of their superiors to achieve high work productivity[8]. Because many people who get personal satisfaction from their work but do not have optimal performance[9], the motivation will encourage someone to move in achieving the desired target, high and low of someone's motivation will determine high and low of the percentage ${ }^{10}$.One that strikes me as particulery useful is to view it as force that drives people to behave in a way that energizes, directs and sustains behavior[11].

Work motivation, according to Terry Mitchell, is defined as a psychological process that causes actions, which has a direction and is continual to achieve goals. Work motivation is based on an individual's belief in knowing the relationship between performance and satisfying various results from different levels of achievement[12].[13] stated that work motivation is something that gives rise to enthusiasm or work motivation. Therefore work motivation is usually called morale booster.[14] Performance is defined as a record of the results obtained from specific job functions or specific activities over a period of time[15], behavior to get things done,[16]. According to [17] To measure employee performance, several dimensions of performance can be used, namely: 1) Quantity 2) Quality 3) Timeliness 4) Cost effectiveness 5) Interpersonal impact (interpersonal relations).

From some of the definitions above, it can be interpreted that performance is the result achieved by a member of Satuan Intelkam Polres Palopo based on certain period of time suitable with his task to achieve organizational goals which include quantity, quality of timeliness and cost effectiveness and the relationship between individuals as members in the organization . 
In addition, the results of research by Conchie, 2013 describe the results of the first and second studies on motivation and belief in safety specifically in transformational leadership, a research survey conducted on the construction industry in the UK to support both studies.

\section{Method}

The approach used by researchers in this case was a qualitative approach which is a research procedure that produces descriptive data in the form of written or oral words of observable behavior, to describe or provide a clear explanation, this is felt to be more sensitive, adaptive and flexible to what was research also makes it easy to understand limited conditions with a deep and detailed focus. The sample in this study is the intelligence unit assigned to the section SKCK Polres Kota Palopo total 3 people.

\section{Result And Discussion}

Based on the findings of the data in the period 2016 to 2019, the number of SKCK applicants at the Palopo Police Station showed a fairly high increase. The data can be seen in Table 1:

\begin{tabular}{cccccc}
\multicolumn{8}{c}{ Table 1. Data of SKCK } & Applicants in 2016 to 2019 Polres Palopo \\
\hline No & Month & 2016 & 2017 & 2018 & 2019 \\
1 & January & 513 & 443 & 510 & 867 \\
2 & February & 279 & 385 & 325 & 452 \\
3 & March & 450 & 593 & 434 & 690 \\
4 & April & 615 & 570 & 713 & 389 \\
5 & May & 457 & 461 & 376 & 456 \\
6 & June & 248 & 494 & 297 & 533 \\
7 & July & 456 & 608 & 1131 & 630 \\
8 & August & 470 & 552 & 668 & 634 \\
9 & September & 362 & 665 & 704 & 623 \\
10 & October & 500 & 307 & 543 & 707 \\
11 & November & 519 & 329 & 386 & 647 \\
12 & December & 402 & 278 & 480 & 369 \\
\hline \multicolumn{7}{c}{ TOTAL } & $\mathbf{5 . 2 7 1}$ & $\mathbf{5 . 6 8 5}$ & $\mathbf{6 . 5 6 7}$ & $\mathbf{6 . 9 9 7}$ \\
\hline
\end{tabular}

According to the results of research in the field, it can be seen that the use of adequate and competent utilization/competence carried out by members of satuan Intelkam Polres Palopo was able to influence the ability of members. In addition, the competencies of the members will determine the results or work performance of the members. Therefore, high results or achievements of members, supported by professional competence and high work motivation, it is expected that the quality of work of members become optimal[18]. This situation states that great work motivation, influenced by motivation from within the members themselves (instrinsic motivation) as the results of interviews conducted with subjects $\mathrm{A}, \mathrm{B}$ and $\mathrm{C}$ recorded showing that being a police officer is their desire so responsibility as servants and managers society is an obligation[19]. 
Expectacy from the existence of members' motivation can be measured from the ability that is believed that work effort will result in the completion of a task[20]. The desire is seen from the possibility (probability) of employee assumptions about the ability of the extent to which achievement is limited by the efforts made[21]. Because this desire is an affiliation between effort and achievement[22]. The results of interviews conducted on research subjects although delivered in different languages but contained the same meaning in which each responsibility given to each subject was a responsibility that must be carried out as well as possible to carry out and obey superiors' instructions.

[23] said that the performance is a record of the results obtained from specific job functions or certain activities over a certain period of time. Performance as a degree of achievement[24]. Meanwhile, according to Campbell, performance is defined as the behavior to get things done[25].

Bernardin and Russel suggested that to measure employee performance factors of performance dimensions could be used[26], namely: 1) Quantity 2) Quality, 3) Timeliness. The research shows that the work quality of Satuan Intelkam members Polres Palopo not only has an impact and is caused by work motivation, but also has an impact and is caused by competence and responsibility.

The findings of the above study are in line with the results of research conducted by Bernardin and Russell which explained that employee performance can be used as a work dimension factor, so the Iltelkam Polres Palopo Unit has provided good service to the community in accordance with established policies.

\section{Conclusion}

This study concludes that work motivation and work competence and responsibility have a positive and significant impact on the achievement of member performance in realizing the quality of SKCK publishing services at Satuan Intelkam Polres Palopo.

The increase in the number of SKCK applicants in Polres Palopo in the last 4 years, namely the year from 2016 to 2019, recorded the number of issuance of SKCK in 2016 as many as 5,271 sheets, in 2017 as many as 5,685 sheets, in 2018 as many as 6,567 sheets and in 2019 as many as 6,997 sheets.

Suggestions for future research are that there are still several important findings that can be developed in future studies, and in the future it is excepted that further research can be done on other factors of the variables that have not been examined. Further research is suggested regarding factors of leadership, organizational climate, management, and in relation to the provision of facilities in SKCK Issuance.

\section{References}

[1] Ismail Cenk Demirko, 2020. The role of police occupational culture on officers' job satisfaction and work motivation, International Journal of Comparative and Applied Criminal Justice. Taylor and Francis Online. doi.org/10.1080/01924036.2020.1742173 
[2] Robbins,Stephen P. (1998). Perilaku Organisasi. USA:Prentice Hall

[3] Kreitner,Robert \& Kinicki, Angelo.(2007). " Organizational Behaviour “, Seventh Edition, Mc.Graw Hill International.

[4] Kreitner, Robert \& Kinicki, Angelo.(2007). "Organizational Behaviour “, Seventh Edition, Mc.Graw Hill International.

[5] Morgan,C.T. (1986). Pengantar Psikologi. Edisi Ketujuh. Singapore : McGraw-Hill.

[6] Conchie SM. (2013). Transformational leadership, intrinsic motivation, and trust: a moderatedmediated model of workplace safety. J. Occup. Health Psychol. 18(2):198-210

[7] Robbins, Stephen P. (1998). Perilaku Organisasi. USA : Prentice Hall.

[8] Mitchell, T. R. (1997). Matching motivational strategies with organizational contexts. In L. Cummings \& B. Staw (Eds.), Research in organizational behavior (pp. 57-149). Greenwich, Conn.: JAI Press

[9] Werner, John. M. \& DeSimone, Randy. L. 2006. Human Resource Development. United States of America : Thomson

[10] Deci, E. L., \& Ryan, R. M. (2000). The "what" and "why" of goal pursuits: Human needs and the self-determination of behavior. Psychological Inquiry, 11, 227-268.

[11] Steers, R. M \& Porter, L. W. (1991). Motivation and work behavior. 5th Ed. McGraw-Hill.

[12] Wood, et.al. (2001). Perilaku Organisasi: A Global Perspective. USA : John Wiley \& Sons Inc.

[13] Wexley, Kenneth N., Yukl, Gary A. (1992). Organizational Behavior and Personel Psychology. USA : Richard D. Irwin Inc.

[14] Byars, L.L. \& Rue. L.W. (2004). Human Resourching Management (7th ed). New York : Mc Graw - Hill.

[15] Byars, L.L. \& Rue. L.W. (2004). Human Resourching Management (7th ed). New York : Mc Graw - Hill.

[16] Campbell, J.P. (1990) Modeling the Performance Prediction Problem in Industrial and Organizational Psychology. In: Dunnette, M.D. and Hough, L.M., Eds., Handbook of Industrial and Organizational Psychology, Consulting Psychologists Press, Palo Alto

[17] Bernardin, H. John. \& Rusell, J.E.A. (1993). Human Resources Management. New York: Mc Graw Hill Inc

[18] Davis , K \& Newstroom. J.W. (1982). Human Behavior at Work : Organizational Behavior. Seventh Edition Singapore : McGraw Hill Book Company Inc

[19] Deci, E. L., \& Ryan, R. M. (2000). The "what" and "why" of goal pursuits: Human needs and the self-determination of behavior. Psychological Inquiry, 11, 227-268. 
[20] Olafsen AH, Halvari H, Forest J, Deci EL. (2015). Show them the money? The role of pay, managerial need support, and justice in a self-determination theory model of intrinsic work motivation. Scand. J. Psychol. 56(4): 447-57

[21] Deci, E. L., Connell, J. P., \& Ryan, R. M. (1989). Self-determination in a work organization. Journal of Applied Psychology, 74, 580-590.

[22] Vansteenkiste M, Neyrinck B, Niemiec CP, Soenens B, De Witte H, Van Den Broeck A. (2007). On the relations among work value orientations, psychological need satisfaction and job outcomes: a self-determination theory approach. J. Occup. Organ. Psychol. 80(2): 251-77

[23] Bernardin, H. John. \& Rusell, J.E.A. (1993). Human Resources Management. New York: Mc Graw Hill Inc

[24] Byars, L.L. \& Rue. L.W. (2004). Human Resourching Management (7th ed). New York : Mc Graw - Hill.

[25] Campbell, J.P. (1990) Modeling the Performance Prediction Problem in Industrial and Organizational Psychology. In: Dunnette, M.D. and Hough, L.M., Eds., Handbook of Industrial and Organizational Psychology, Consulting Psychologists Press, Palo Alto

[26] Bernardin, H. John. \& Rusell, J.E.A. (1993). Human Resources Management. New York: Mc Graw Hill Inc 